\title{
Conservation Science Policies Versus Scientific Practice: Evidence from a Mexican Biosphere Reserve
}

\author{
Gabriela Alonso-Yañez ${ }^{1}$ \\ Werklund School of Education \\ University of Calgary, Canada \\ Conny Davidsen \\ Geography Department \\ University of Calgary, Canada

\section{Abstract}

This paper interrogates the activities, perspectives, and positions of scientists conducting research in Sierra de Huautla Biosphere Reserve, Mexico. Biosphere reserve conservation models are specifically designed for a sustainable integration of social and natural environments, a mandate that relies on both natural and social scientific research to improve conservation of nature and human well-being. Seen through the analytical lens of a social worlds/arenas framework, integrative scientific research in this particular case proves to be challenging in practice and fraught with paradoxes and contradictions. The findings suggest that academic and institutional factors (funding, publication avenues, and scholarly status) force, or at least strongly invite, scientists to pursue academic research agendas which, in fact, may conflict with or override the researchers' own commitments to meaningful conservation research work and interventions. This case highlights structural concerns over biosphere reserve-specific governance issues in Mexico, and integrative human-environment scientific practice in conservation in general.

Keywords: biosphere reserves, conservation, environment and development, interdisciplinary research, local benefit, politics of science, situational analysis

\section{Introduction}

The biosphere reserve was conceived by the United Nations Educational, Scientific and Cultural Organization (UNESCO) as an integrative conservation model to reconcile the needs of human and natural environments. From its beginnings, the biosphere reserve model represented a special conservation approach where ecological protection is integrated with the needs of the local

1 Corresponding author: galonsoy@ucalgary.ca. 
population, based on sustainable human-environment interfaces within the designated park boundaries (Halffter \& Ezcurra, 1989; UNESCO, 2013). The idea was explicitly based on a threefold set of complementary functions (Halffter, 2011): (1) conservation, (2) development (or social integration), and (3) research. The third function even describes the reserves as "living laboratories for testing out and demonstrating integrated management of land, water and biodiversity" (UNESCO, 2013). Under these three functions, conservation is implemented through tiered land-use designations within the protected area that allow for different levels of resource use for the local populations. Social integration and development includes formal and informal partnerships with a range of interested organizations, research institutions, communities, and individuals (Halffter, 2011; Stairs, 2007; Gomez-Pompa \& Dirzo, 1995).

The idea of integrating human needs with environmental protection, embedded in continuous scientific efforts, has earned the biosphere reserve conservation model considerable enthusiasm, support, and advocacy across Latin American conservationists over the past decades (Halffter, 2011; Halffter \& Ezcurra, 1989). Mexico in particular prioritized the establishment of what has been called the "Mexican modality" of biosphere reserves (Halffter \& Ezcurra, 1989; SantanaCastellón, 2013; Stairs, 2007). To add local emphasis, the national policy required that the biosphere reserve was fully embedded in, supported, and desired by the local level (Halffter \& Ezcurra, 1989, p. 194). An important feature of the Mexican modality was "to give the [biosphere] reserves administrative independence by commissioning their management to research institutions that respond to the higher (state and federal) authorities of the country" (Halffter \& Ezcurra, 1989, p. 195). The Mexican biosphere reserves were to be brought up by an alliance between university conservationists and local communities. As biocultural approaches to the conservation of land, biosphere reserves were planned as spaces that directly linked management and scientific research to develop adaptive management strategies and places where legitimate stakeholder participation platforms were provided in reserve management. Moreover, biosphere reserves were to be places where environmental outreach and community education programs exist as multidirectional communication mechanisms. The Mexican modality of biosphere reserves was a policy later adopted by international nongovernmental organizations, such as UNESCO's Man and the Biosphere Programme, due to its promising scientific practice link (Halffter \& Ezcurra, 1989; Santana-Castellón, 2013).

Given that scientific research is one of the biosphere reserve mandates, particularly significant in the Mexican modality, this article seeks to provide further insight into the realities of scientific practice at the conservation research-practice interface. It focuses on examining how the integrative goal of the biosphere reserve model — namely, conducting interdisciplinary research- 
is pursued by a particular group of scientists at a biosphere reserve research center. Our study examines the types of research in which the scientists of the center engage; their perspectives regarding the goals of conservation initiatives; their perspectives on the institutional conditions of the research center; and the limitations and pressures that influence their priorities and behaviors regarding conservation research and practice. Our research attempts to understand science in conservation and highlights the specific non-conformity between the expectations of conservation advocates and the problematic realities of conservationists (particularly scientists) on the ground.

\section{Challenges for the Mexican model}

Mexican biosphere reserves, especially those associated with a research institute or laboratory, have been praised for their contributions to the production of knowledge on biodiversity in tropical ecosystems (Castillo \& Toledo, 2000; Halffter, 2011; Martínez et. al., 2006). However, little is known about the extent to which biosphere reserves have fulfilled the commitment to address interdisciplinary research and promote locally relevant socio-environmental solutions. Several analyses on Mexico's biosphere conservation over the past decade suggest that Mexican biosphere reserves have come to exhibit a systemic failure of social integration and research (Contreras-Hernández, 1991; Durand \& Jiménez, 2010; Gerritsen, 2002; Halffter, 2011). For instance, Young's work in El Vizcaíno (1999) reported that local communities had no choice but to participate in pre-planned conservation projects designed by governmental and academic actors. The initial establishment and subsequent management of the biosphere reserve not only failed to address broad social problems within the region, but also criminalized the livelihoods of some of Mexico's most impoverished land dwellers. Similarly, the work of Gerritsen in Sierra de Manantlán (2002) and of Contreras-Hernández in El Cielo (1991) describes how these biosphere reserves were planned by outside researchers and the rules and park zones designated by state governments. Both reserves were and continue to be managed without prior consultation with local residents. For the most part, no effort was made to enhance the residents' participation in managing the biosphere reserve. Equally troubling is the poor record of Mexican biosphere reserves in conducting research to improve the social conditions of biosphere reserve inhabitants. Several studies conducted in Mexican biosphere reserves have lamented the conditions of local inhabitants and indigenous groups involved in conservation strategies (Durand \& Jiménez, 2010; Gerritsen, 2002; Young, 1999). While research is a central objective and explicit mandate of biosphere reserves, most of the research by management-partner institutions has been found to reinforce a traditional and narrow biological focus (Figueroa \& Durand, 2011; Halffter, 2011; Urquiza-Haas, 2009). 
Despite the growing findings on a problematic gap between the integrative mandates of biosphere reserves - including a gap between conservation research and practice - only recently did scholars raise the question that it may have something to do with failures in the underlying practices and experiences of conservation research itself (Campbell, 2010; Durand \& Vázquez, 2011; Sievanen et al., 2012). For example, the fact that professionally, academics are essentially evaluated on their research performance - that is, their publication record and how this metric impacts their performance and diverts researchers from the ultimate goal of conservation biology - is just recently being studied (Arlettaz et al., 2010; Chapron \& Arlettaz, 2008).

A rare and interesting study by Castillo \& Toledo (2000), for example, about the involvement of scientific researchers in applied conservation in Mexico found that only a small number of projects contributed to the larger development of applied ecology research in Mexico, and that the institutional research focus was often influenced not by such goals but by the structures of academic rewards.

Over the past 16 years, the Mexican government has actively promoted the strengthening of natural science-based research to inform conservation strategies in natural protected areas (Halffter, 2011). As a result, biosphere reserves have become a cornerstone of Mexico's conservation policy. They are one of its most widely used policy instruments for land-use protection and boast the second-largest number of biosphere reserves (41 in total) in the world, covering nearly 6.5 percent of the country (Comisión Nacional de Áreas Naturales Protegidas, 2012).

Over time, Mexico's environmental administration and proud leadership on biosphere reserves somewhat cemented itself into a mindset that the presence of scientific efforts would guarantee conservation success (Blauert \& Dietz, 2004; Simonian, 1995; Stairs, 2007). The government incorporated a large number of natural scientists into its staff in order to increase the natural science dimensions of conservation research. However, the hiring wave of natural scientists has been found to de-emphasize the social and political aspects of integrative conservation - regardless of the critical decision-making, agenda setting, and management of protected areas in ways that often resonate beyond government policy-making (Durand \& Lazos, 2008; Durand \& Vázquez, 2011; Halffter, 2011; Stairs, 2007). In particular, the Mexican modality granted considerable management authority of the biosphere reserves to the research institutions, largely outside the reach of local authorities and reporting directly to the state and federal authorities that decreed the biosphere reserves (Halffter \& Ezcurra, 1989).

More than two decades into its conservation science policy efforts, the Mexican government has now conducted systematic reviews of the protected- 
area system and, in 2009, released a comprehensive, state-of-the-art, national review of its biodiversity conservation system (Koleff \& Urquiza-Hass 2011; Urquiza-Haas, 2009). The large-scale government review centered on assessing the ecological effectiveness of the Mexican network of national protected areas and concluded, for example, that 11 ecosystems are underprotected within the system, addressing questions of conservation effectiveness and representation (Bezaury-Creel \& Gutiérrez-Carbonell, 2009; Dirzo et al., 2009; Halffter, 2011). The review paid less attention to the network's performance in terms of social involvement and interdisciplinary and cross-discipline research performance.

While there is abundant research on conservation challenges and failures of integrative conservation models, most research reports challenges and failures in relation to local communities, government staff members or nongovernment agencies. There is a lack of work focused on the work of conservation scientists in practice. Natural resource management policies continue to emphasize the idea that the science behind conservation efforts can guarantee successful conservation efforts as if it were removed from the political and social environment around it. This assumption permeates conservation narratives of most international lending institutions, government offices, and nongovernmental organizations involved in natural resource management planning and development initiatives. Therefore, we feel it is our role as scientists to continue to seek ways to identify and unveil the very complex sociopolitical processes at stake in conservation science practice.

\section{The Sierra de Huautla case study}

Sierra de Huautla first became a protected area of the State of Morelos in 1998, then a biosphere reserve in 2006 as part of the international UNESCO Man and the Biosphere Reserve Programme (UNESCO, 2013). The area's upgrade into an internationally recognized biosphere reserve came at a time when Mexico's biodiversity conservation agenda had developed a strong political momentum, embedded in a considerable scientific support network from government agencies and academia (García-Frapolli et al., 2009; Stairs, 2007). The upgrade was also influenced by a collaborative effort between researchers at the Autonomous University of the State of Morelos and Rancho Santa Ana Botanic Garden of Claremont, United States, who were advocating for its creation because of its ecological significance. Sierra de Huautla's endemic forest vegetation-tropical dry forest-had become recognized as one of the most threatened in the country, forming part of a dominant tropical ecosystem of the neotropics that reaches from Mexico's northern Pacific coast to the state of Chiapas (Noble \& Dirzo, 1997).

Sierra de Huautla Biosphere Reserve is the home of 31 communities across six counties and is co-governed by the National Commission of Natural Protected 
Areas, as the legal administrative authority for the area, and a local research center that was founded at the time of the creation of the reserve, specifically mandated with the monitoring of the biological and social conditions of the reserve. Linking area-specific conservation research centers with natural protected areas had become a favorable and strategic instrument often chosen for new protected areas, reflecting the Mexican modality of local embeddedness and the country's conservation commitment to a stronger research-practice link (Blauert \& Dietz, 2004; García Frapolli et al., 2009; Simonian, 1995; Stairs, 2007). As such, the area's research center provides a relatively typical setting with regard to the time, political context, and location of a biosphere reserve center as it reflects common research-practice links in Mexico's biosphere conservation practice.

The Sierra de Huautla research center is run as a division of the Autonomous University of the State of Morelos on the main campus in Cuernavaca City. Called "the Mexican capital of knowledge" (Academia de Ciencias de Morelos, 2012), Cuernavaca boosts the largest number of scientific research centers in the country and is conveniently located just outside (60 kilometers) Mexico City's diverse research infrastructure. At the time of our study, the research center was subdivided into three departments: two conducting research in natural aspects of the reserve-Evolutionary Ecology, and Taxonomy and Systematics-and one conducting research into the social aspects of the reserve-Resource and Environmental Management and Environmental Education. Scientists who were members of the Evolutionary Ecology department focused their research on the evolutionary histories of species and the interactions between them, while scientists in the Taxonomy and Systematics department focused on the identification and classification of organisms. Scientists working in the Resource and Environmental Management and Environmental Education department studied the integration of human and natural environments.

\section{Methodology and research design}

The purpose of our study - examining the work and scientific practice of researchers in Sierra de Huautla Biosphere Reserve-directs the methods of data gathering and analysis to be within the realm of qualitative inquiry. Our research focused on ground-level qualitative work, the activities of conservation scientists. We relied on situational analysis (Clarke, 2005) to collect and interpret textual, interview-derived, and field-derived data.

Within situational analysis methodology, the central analytical perspective we used in the study is the social worlds/arenas (SWA) analysis, embedded in a political ecology perspective. The SWA framework for analysis has proven to be useful in the analysis of scientific work from a sociological perspective 
(Clarke, 1991; Fujimura, 1987; Gerson, 1983; Tuunainen, 2005), and it has particularly been linked to science and technology research that examines the ways through which the production of science and technology become interlaced with social norms and hierarchies (Jasanoff, 2004), such as the work of scientists in conservation projects that ultimately affect the way conservation science is decided upon and practiced in society. The perspectives of scientists and their commitment to conservation priorities actively shape their work and also affect the way they organize their work, individually and collectively. The SWA approach is deeply rooted in the long tradition of examining scientific practice, disciplinary fields, and scientific production groups with particular focus on locally, historically, and institutionally situated interactions among scientific disciplines, specialties, and research traditions composed by individuals and collectives (Clarke \& Star, 2007; Fujimura, 1987; Tuunainen, 2005).

The SWA framework defines social worlds as "groups with shared commitments to certain activities, sharing resources of many kinds to achieve their goals, and building shared ideologies about how to go about building their business" (Clarke, 1991, p. 131). Examples of different social worlds could be groups of educators, students, and administrators that coexist in an educational institution, embracing different ideologies over their work and expressing them through different professional activities, languages, and modes of relation (den Outer et al., 2013). Similarly, the different collective groups that have a stake in conservation practice, such as ecologists, taxonomists, and ethnobotanists who are members of various scientific disciplines, specialties, and research traditions, are examples of a social world. Social worlds are composed of individual agents who also bring personal agendas and commitments to action (Clarke, 2005).

The SWA framework was selected for this analysis due to the way in which it allows a consideration of larger sociopolitical issues as constituents of conservation practice. As such, this approach also follows longstanding calls from political ecology researchers to put more emphasis on "the politics involved in the processes of conservation and the social and material struggles to which they give rise" (Büscher, 2013, p. 3).

Our analytical focus on the underlying scientific and social practices in conservation science follows recent political ecology perspectives in that it seeks to analyze the ways in which environmental projects seek legitimization by "portraying [themselves] as being outside of politics," as Büscher (2010, p. 29) has put it. Our work builds on an extensive body of political ecology research that has traditionally highlighted the inherently political nature of humanenvironment processes, and outlined the political forces within conservation; for example, in social conflicts over forest resources, protected areas, agricultural regimes, and productive regions (see Baker et al., 2012; Brockington et al., 2006; 
Brockington \& Schmidt-Soltau, 2004; Bryant \& Bailey, 1997; Büscher, 2013; Lane, 2003; Le Billon, 2001). We attempt to contribute to the emerging political ecology research that has, together with the science and technology literature, helped uncover the political character of conservation science-in other words, the politics behind the scientific practice upon which environmental policies and conservation are built (Cairns, 2011; Forsyth, 2008; Forsyth \& Sikor, 2013; Kellert et al., 2000; Vayda \& Walters, 1999).

\section{Data collection at the Sierra de Huautla Biosphere Research Center}

The data were collected over a period of two years (2010-2012) at Sierra de Huautla Biosphere Reserve through on-site fieldwork, in-depth interviews, and analysis of scientific texts. Members of the research center in the data collection period comprised 20 early-career scientists (around 35-45 years old) holding a master's degree or a $\mathrm{PhD}$. At the outset of our project we contacted all 20 scientists working in the center, but only eight agreed to be interviewed. During the recruitment process of participants for the study we found that many researchers we approached did not consider themselves eligible or relevant for the study because their research was not related to, or even carried out in, Sierra de Huautla.

Seven interviews were conducted in person at the scientists' offices and one interview was conducted over the phone. The background information of the interviewees is summarized in Table 1. 
Table 1. Attributes of participating researchers

\begin{tabular}{|c|c|c|c|}
\hline Participants & Training/trained priorities & $\begin{array}{l}\text { Network resources and } \\
\text { information access }\end{array}$ & $\begin{array}{l}\text { Experience and } \\
\text { tenure }\end{array}$ \\
\hline $\mathrm{P} 1$ & $\begin{array}{l}\text { PhD natural sciences/ } \\
\text { plant systematics and } \\
\text { evolution }\end{array}$ & $\begin{array}{l}\text { Activism for } \\
\text { conservation. } \\
\text { Collaboration with other } \\
\text { academic peers. }\end{array}$ & $\begin{array}{l}\text { Permanent position in } \\
\text { research center }\end{array}$ \\
\hline $\mathrm{P} 2$ & $\begin{array}{l}\text { PhD natural sciences/ } \\
\text { listing of entomological } \\
\text { species; curator }\end{array}$ & $\begin{array}{l}\text { Most research activities } \\
\text { laboratory based. } \\
\text { Collaboration with other } \\
\text { academic peers. }\end{array}$ & $\begin{array}{l}8 \text { years in BR } \\
\text { Trial period position }\end{array}$ \\
\hline P3 & $\begin{array}{l}\text { PhD natural sciences/ } \\
\text { biogeography; listing of } \\
\text { entomological species }\end{array}$ & $\begin{array}{l}\text { Most research activities } \\
\text { laboratory based. } \\
\text { Collaboration with other } \\
\text { academic peers. }\end{array}$ & $\begin{array}{l}8 \text { years in BR } \\
\text { Trial period position }\end{array}$ \\
\hline $\mathrm{P} 4$ & PhD ecology/zoology & $\begin{array}{l}\text { Most efforts and plans } \\
\text { focus and depend on } \\
\text { academic resources. } \\
\text { Collaboration with other } \\
\text { stakeholders besides } \\
\text { academic peers. Has } \\
\text { gradually become more } \\
\text { involved in administrative } \\
\text { functions of the BR. }\end{array}$ & $\begin{array}{l}14 \text { years in BR } \\
\text { Director of research } \\
\text { center } \\
\text { Permanent position }\end{array}$ \\
\hline P5 & $\begin{array}{l}\text { PhD ecology/ecosystem } \\
\text { functions, ecotoxicology }\end{array}$ & $\begin{array}{l}\text { Most resources and } \\
\text { projects are academic. }\end{array}$ & $\begin{array}{l}7 \text { years in BR } \\
\text { Trial period position }\end{array}$ \\
\hline P6 & $\begin{array}{l}\text { PhD ecology/ } \\
\text { ecotoxicology }\end{array}$ & $\begin{array}{l}\text { Most work focus is } \\
\text { directed toward scholarly } \\
\text { journals. }\end{array}$ & $\begin{array}{l}7 \text { years } \\
\text { Trial period position }\end{array}$ \\
\hline P7 & $\begin{array}{l}\text { Master of Science/ } \\
\text { projects of conservation } \\
\text { in local communities } \\
\text { and coordinator with } \\
\text { government agencies }\end{array}$ & $\begin{array}{l}\text { Most projects and work } \\
\text { focus involve regulatory } \\
\text { documents. }\end{array}$ & $\begin{array}{l}5 \text { years in } \mathrm{BR} \\
\text { Trial period position }\end{array}$ \\
\hline P8 & $\begin{array}{l}\text { Master of Science/ } \\
\text { botany, ethnobotany, } \\
\text { resource and } \\
\text { environmental } \\
\text { management }\end{array}$ & $\begin{array}{l}\text { Most projects involve } \\
\text { regulatory documents. }\end{array}$ & $\begin{array}{l}18 \text { years in BR } \\
\text { Permanent position }\end{array}$ \\
\hline
\end{tabular}

The interviews first addressed the participants' conservation perspectives. We explicitly solicited their views on the work of six prominent conservation scholars well known by all interviewees. Three scholars were offered as examples of rigorous "protectionist, natural science--based" approaches (John Terborgh, Kent Redford, Daniel Janzen) within conservation literature, and three were used as proponents of "people-oriented" approaches whose work advocates for the inclusion of a social dimension in conservation research and practice (Victor Toledo, Julia Fraga, Janice Alcorn). We asked the eight interviewees to identify 
the scholars from the list whose work they considered important, inspiring, and/or similar to their own work in the biosphere reserve. We also asked them to describe their views on the value of nature vis-a-vis humans and their ethical arguments for conservation. The interview then asked about the participant's personal and professional background in the biosphere reserve, followed by questions about their collaborations, intellectual synergies, and professional relationships in order to determine the participant's priorities and agendas.

The in-depth analysis of interviews then informed further data collection (Clarke, 2005; Glaser \& Strauss, 1967) that included university-related institutional management, academic employment conditions, research policy documents, and the researchers' own research articles. We used Google Scholar search engine to track down the types of research programs and lists of published works for each individual scientist, including those presented in the center's reports. We searched specifically for information regarding the research site; for instance, whether the research was conducted in Sierra de Huautla Biosphere Reserve and whether the research was published in English or Spanish. We also reviewed three current government evaluations concerning the National System of Researchers in order to have a full account of the origins of the program and the current performance of conservation scientists in Mexico.

The purpose of gathering more data was in response to our interest in comparing the information given by interviewees (e.g., research activities versus products relevant for Sierra de Huautla Biosphere Reserve). This data-gathering technique attempts to trace the researchers" "vocabularies of motive" (Clarke, 2005 p. 22). The purpose of this sampling strategy was to directly explore the relationship between verbalizations (actual answers/statements) and the motives (normative cultural/contextual regulations) that framed those answers. In other words, we were seeking to account for what scientists "said they were doing" and "what scientists were actually doing."

All interview data were organized into transcribed and translated segments of 3-5 minutes for a qualitative data analysis aided by the computer software NVivo. Following Clarke's (2005) situational analysis methods, we carried out initial open coding and produced over 34 codes for each interview. We compared the codes in order to identify similarities and differences, and to develop larger themes (Clarke, 2005; Corbin \& Strauss, 1990).

\section{Analysis: Challenges to integrative conservation research}

The data outlined three major areas of focus or concern: first, an asymmetry between the amount of natural science and social science research that is 
conducted in Sierra de Huautla Biosphere Reserve; second, we identified barriers to locally relevant research because of counter-directed institutional incentives; and third, both these problems are inclined to grow further given the social and political context of the research center.

\section{Balance between natural and social science research}

In contrast to the declared goals of integrated research particular to the biosphere reserve model and emphasized since the creation of this particular research center in Sierra de Huautla, there is a strong emphasis on natural sciences in the center's composition of scientists, resources, and programs. Out of 20 researchers employed at the research center, only two were associated with social sciences. Over 90 percent of the center's funding and resources was allocated to natural science research, while the social science department held about 9 percent of annual budgetary funds. Collaborations of the research center were held mainly with other academic units that were dedicated to the natural sciences; for example, with the Institute of Biotechnology, and Institute of Biological Sciences.

The clear natural-social science asymmetry observed in the annual report documents in terms of funding, resources, and number of staff trained in the social sciences working within the research center was also reflected in the composition of academic researchers recruited for this study (Table 1).

The in-depth interviews with each of the participating researchers explored their perspectives as outlined in the methods section above. The conservationrelated beliefs were situated between protectionist and people-oriented as counter-directed positions for reference, complemented by interviewee responses about the value of nature vis-a-vis humans, the ethical arguments for conservation, and the type of research collaborations scientists described as priority for their work (number of projects carried out in collaboration with social scientists). Although some heterogeneity of perspectives and views was evident, statements from interviews showed a clear position of scientists on core issues and a tendency to prioritize natural science-based research and the need to concentrate efforts on protecting the natural state of the ecosystem. The participants' science-related beliefs were categorized based on their descriptions regarding the type of research they considered more effective and relevant for conservation projects.

The researchers who endorsed a protectionist approach for conservation (Table 2) argued that the conservation and maintenance of biological processes should be prioritized in conservation projects and that one way to do so was to "follow the scientific method" to understand and intervene in the conservation of Sierra de Huautla Biosphere Reserve. The five participants who expressed 
protectionist views also emphasized the singular importance of natural science research for the planning of conservation projects, as opposed to a move toward an integration of the contribution provided by local knowledge. They would refer to the need to "educate" local community inhabitants and to "test" their views about biophysical events rather than recognizing the contributions of local knowledge toward integrative conservation management and goals.

Table 2. Conservation priorities: Conservation- and science-related beliefs of researchers

\begin{tabular}{lll}
\hline & Protectionist approach & People-oriented approach \\
\hline $\begin{array}{l}\text { Conservation } \\
\text { position }\end{array}$ & P1, P2, P3, P4, P6 & P5, P7, P8 \\
& $\begin{array}{l}\text { Nature has intrinsic value. } \\
\text { Practices of local inhabitants } \\
\text { cause environmental degradation. }\end{array}$ & $\begin{array}{l}\text { Inhabitants should be the ones } \\
\text { setting the terms for conservation } \\
\text { measures as they inhabit the area. }\end{array}$ \\
& $\begin{array}{l}\text { P1, P2, P3, P4, P6 } \\
\text { Natural science needs to be } \\
\text { prioritized over social science } \\
\text { research because people } \\
\text { mostly negatively affect their }\end{array}$ & $\begin{array}{l}\text { P5, P7, P8 } \\
\text { surroundings. }\end{array}$ \\
& social and natural science research \\
& to inform comprehensive projects.
\end{tabular}

Note: $\mathrm{P}=$ participant (see Table 1 ).

"So the thing here is that: for us [scientists] the most important part is the environment, not the humans, and for them [local inhabitants] is the opposite" (P3).

Local knowledge provided by community inhabitants can be the basis for further scientific knowledge. The thing is that local knowledge does not have any scientific basis. It can become the base for developing science. This rustic, rudimentary, non-scientific knowledge that people have about their environment can be, probably, tested and thus prove to be "strictly real" and used for conservation decisions. (P4)

The current director of the research center concentrated his efforts on supporting the natural science units and referred to the need to adjust to the organization requirements set by the university academic regulatory frameworks, as he explained:

As the research center's director, I need to coordinate what is done collectively in this institution. I have to be sure that the work is good and that we comply with the perspectives and academic regulations of the whole university. My function within the center is to make sure we have a good organizational performance and resources to achieve the mission of the center which is related to maintaining the biodiversity and the biological conditions in the BR. (P4) [emphasis added] 
Most participants emphasized in one way or another that the overall goal of conservation was to allow biological processes of adaptation and evolution to continue without interference. Some of these participants identified specific types of biological research they considered should be prioritized, such as research concerning genetic traits or long-term assessment of biodiversity features. For the five participants who held a protectionist view, the work of social scientists was not regarded as a valuable priority in itself but as a supplementary or optional contribution to conservation. Some participants even expressed open mistrust towards conservation projects that were directed by social scientists, as the following example illustrates:

These people have good intentions and, ostensibly, would know how to manage conservation, but they really do not know anything. They are not experts, they are anthropologists or sociologists and so they do not know anything about conservation. Nothing! They are fake conservationists. (P1)

The three scientists who were more aligned with a people-oriented approach to conservation were actively participating in research projects that involved social scientists in the center, such as the development of community needs assessments and the design of educational materials for local communities. One of them stressed, however, that while he had collaborated in multidisciplinary teams earlier in his career as a student, currently he did not see a conducive environment in the research center for interdisciplinary research with peers from other academic backgrounds:

Nowadays we are focused on laboratory research and work that does not involve local communities because it is easier. Here in the research center I have worked more in the laboratory than in the field because working with people is complicated and there are no projects held collaboratively. (P5)

Another of the participants supporting a people-oriented approach described how difficult it was for her to "convince" other researchers of the importance of an integrative approach to conservation and biodiversity management:

This is an everyday effort, from a small chat in the hallway to a serious discussion in an academic committee. I have to stand up for my work in the face of other collaborators who, even now, believe that integrating local people in conservation is not a priority. My work is not considered "scientifically" relevant within the center. (P8) 


\section{Local relevance and engagement in the biosphere reserve}

Another finding of our study was that even within the amount of biological research carried out in the center, there was a lack of connection and engagement with local conservation activities, their planning, and management of priorities and goals in the biosphere reserve. As mentioned in the methods section, even the mere recruitment process of participants for this study revealed a lack of local identification of many scientists at the research center. Moreover, scientists interviewed made continuous reference to a divide between science and action and the challenge to pursue research that had a concrete impact on conservation practice for Sierra de Huautla Biosphere Reserve.

You have to choose between working on theory or practice when you do conservation. My students ask me many times: what is the importance or relevance of our work about insects? My answer is that we need to do this part of the work and then maybe, perhaps later with our information, someone else will come and make the link with practical uses of the information for conservation. We cannot do everything. (P3)

Linking research outcomes with conservation in the same time scale is not necessary. I am sure that if we list one new species we are not conserving. Basic biological research is good; however, alongside research activity, we need to find ways to carry out other activities that help conserve the place in the short term. I can tell you now that all the scientific production developed by the research scientists have not impacted in any way the conservation of the area. (P2)

We reviewed the research center's annual reports 2008-2011, as well as other information on the center's ongoing research activities. In order to enrich the data, we searched Google Scholar for publications in natural sciences for the years 2008-2012 that contained the name of the Sierra de Huautla Biosphere Reserve. Our analysis of the ongoing research activities of scientists was based on the following criteria: (1) whether the research projects (published by scientists from the center) were conducted in the biosphere reserve or concerned life forms particular to this site, (2) the number of cross-disciplinary studies, and (3) studies of loss of native vegetation and wildlife.

The research center reported production of 39 scientific articles in a two-year period, of which only 12 were conducted in the biosphere reserve or concerned ecological matters specific to the reserve. The Google Scholar search retrieved 343 articles, 22 of which were authored by researchers of the center. While the natural science-based research contribution of the center was globally significant in terms of generalized biological knowledge production (assessed 
based on their abstract claims and academic quotations), references to the local context or relevance of the conducted research for Sierra de Huautla were nearly non-existent. Similarly, the research center's annual reports presented its scientific production based solely on scholarly contributions in relation to the impact factor of the scientific journal in which articles were published, missing descriptions of any conservation-related impact, local relevance, embedded research or community activities in the biosphere reserve.

Our analysis of the interview data regarding scientist's positions (Clarke \& Friese, 2007) offers insights as to why scientists did not prioritize locally relevant research within the biosphere reserve. We also examined researchers' statements regarding their internal and external incentives and limitations at the research center as these affect their scientific work in principle or in practice. Figure 1 summarizes the reported information of interviewees regarding the priority they assigned to the publication of articles over locally relevant research pertaining to the biosphere reserve (vertical axis) and the priority they assigned to conducting research in the biosphere reserve (horizontal axis).

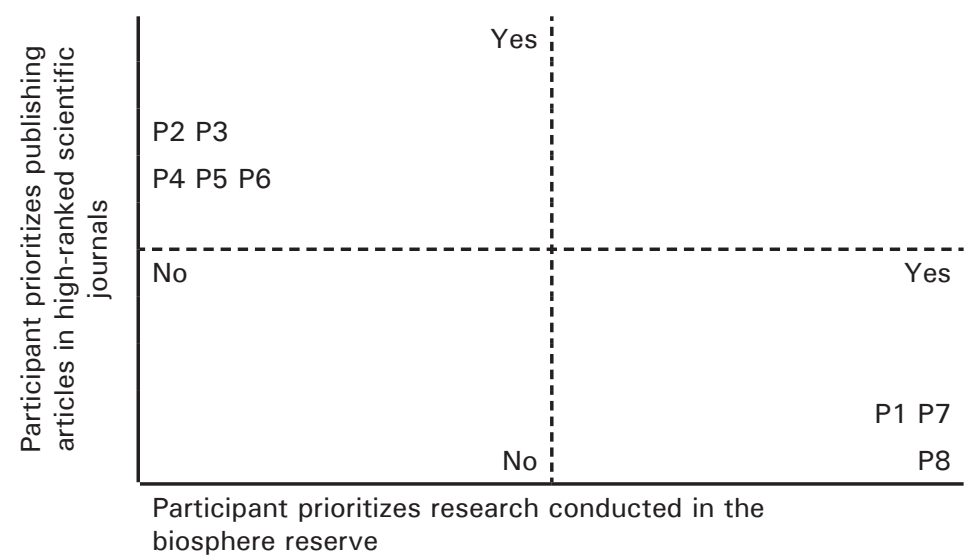

Figure 1. Positions of scientists' research priorities

Most scientists (P2, P3, P4, P5, and P6) identified a clear priority on publishing articles in high-ranked journals over a local engagement in research that would be pertinent to the biosphere reserve. They argued that research on the local biological and ecological processes specifically embedded in the local ecosystem of Sierra de Huautla was discouraged by their work environment, while generalizable biological research output was encouraged and favored.

\section{Both trends continue: Natural/social science research and local conservation engagement}

Across all participants, our data indicate a clear and pragmatic encouragement of the center's institutional system and the researchers' social worlds toward 
foundational biological research, growing further away from locally embedded projects and toward short-term generalizable ecological research that offers a larger audience and publication access to higher ranked journals. As the researchers explained, locally specific conservation research such as forest and landscape restoration projects, local monitoring needs and practices, population sizes, or local species biodiversity require scientists to engage in long-term research projects over more years than laboratory research and cannot guarantee that they would result in publishable products. Those researchers who depended on frequent academic assessments in order to renew their employment contracts stressed this issue:

Nowadays, being a researcher means publishing. You need to have products that are relevant for the broader field. If your products are not globally significant, you will probably not publish in a high-ranked journal. You can publish, but then your research results have only local impacts. The impact factor is low because it is local. It seems that if the results are locally relevant, nobody will read that. And then you fail to comply with the university's evaluation requirements. The institution is the one that sets the requirements. You need to publish in journals with a high impact factor. You have to decide where you want to play. (P5)

The five interviewees who strongly prioritized publishing articles (Figure 1) further elaborated that their main incentive for collaborative research projects was to boost their scholarly output, not the development of new research activities that could potentially be relevant for the area.

Realistically, our objective is to contribute to listings of entomological species. We contribute to generate information about insects at a national level. We mostly collaborate with researchers and museums outside Mexico. For instance, Museum of Los Angeles, University of Kansas, and we assure quality research products. (P2)

Moreover, interviewees indicated that initiatives and efforts toward multidisciplinary approaches were typically marginalized in the research center in terms of resource support, infrastructure, and opportunities for larger collaborations. One interviewee explicitly blames the high competition between integrated and non-integrated conservation research perspectives in academic practice:

The team of TAs [technical assistants], RAs [research assistants], and myself are outnumbered by those researchers who focus their work on exclusive biological-oriented research. This is reflected in the impact of our work that is not visible in the overall performance of the center. (P8) 
The participants were recruited from different organizational levels and sub-units of the research center, from administration (director) at the center of authority to research staff at the periphery. They have different access to decision-making and agenda setting regarding the strategic priorities, research management, and resource administration of the center. The direct interviews and triangulation indicate that those scientists who are involved in multidisciplinary work hold less influential roles in the research center, which potentially reproduces a further marginalization of multidisciplinary or transdisciplinary approaches among the competition over resources, influence, and priorities in the center.

Despite that fact that descriptions of projects for education and biodiversity were lacking in the biosphere reserve center's report, evidence of such activity was found elsewhere. For instance, earlier documents and references indicated that the research center used to run a series of public outreach projects for education and biodiversity awareness (Dorado et al., 2002). Various projects tried to increase social ties with the local communities in the biosphere reserve and increase local environmental awareness of the general public. For instance, research center staff developed educational resources, posters, leaflets, and banners about animal and plant species that were used for public outreach in local communities and schools to create awareness of the region's biodiversity. These projects were designed collaboratively between research center staff and members of the local community (Reyes Morales \& Dorantes Flores, 2007). The research center even ran two radio shows and a TV show for biodiversity-related outreach in partnership with the state university and the state government office of communication, offering local news and environmental education programming. However, the 2010-2012 annual reports that we reviewed did not make any reference to these outreach activities. The 2008-2009 annual reports referred only vaguely to the participation of the center's scientists in public outreach formats, interviews, and radio shows.

Many interview participants recalled that these outreach efforts struggled due to lacking academic recognition and increasing marginalization at the center, which led to their discontinuation although they had once been the core objectives of the center. The interviewees stated that the center's evaluation and reward mechanisms systemically favored foundational biological research and its scientific publication in high-ranked journals over the broader academic activities that served public engagement and the center's local integration mandate. This marginalization was further enforced by the purely scientific assessment criteria of the university system they were part of, and on which they relied to renew their academic positions. As a result, the pressure to publish and deliver scientific products - measurable only through academic publications added to the increasing disconnect between social and biological conservation activities in biosphere reserve. 
Some excerpts from participants' statements are reproduced below.

Around the year of 2000, the biology honors program at UNAM [Autonomous University of the State of Morelos] was changed and most biologists currently working in Mexico come from this university. The new program clearly encouraged more work in the laboratory in fields like molecular ecology and, in general, fields that are mostly lab-focused. The work in the lab is much easier; you get your material, you study that material and that's it. I do not have to worry about asking for permits or going to collect, I just work with those collections and I can publish a lot. (P5)

Nowadays, it is only me developing teaching materials because here, most researchers are not contributing to develop outreach projects. I believe that these programs are important because they are conservation strategies that really impact the public. But currently, researchers are more interested in their own personal agendas, which I respect. It is the system that asks you to do that and you have to choose. (P1)

The recent history of the research center itself shows how the re-orientation toward foundational biological research has become reinforced through new administrative changes. As several interviewees (P1, P2, P3, P7) describe, the center's 2008 appointment of a new director coincided with a shift of research focus away from social research toward a stronger biological and ecological emphasis. The public records of the research center indicate that two years after the new director's appointment, the center's original name "Center for Environmental Education and Research of Sierra de Huautla" was changed to "Center for Research in Biodiversity and Conservation" to re-label the center's research content and activities away from a local focus on the biosphere reserve to a more general biological scope (Gallardo, 2010; González, 2010).

Along with the described systemic discouragement of local engagement, our interviewees noted that the erosion of applied research and local engagement at the research center was further exacerbated due to simple geographic barriers of logistics and distance. The center is based in Cuernavaca; three hours away from the biosphere reserve. Several interviewees argued that having their offices closer to the reserve would indeed make a difference in their involvement with local communities in the area. At the same time, they were reluctant to support a move of the research center closer to the biosphere's rural environs because they feared impacts on their lifestyle and family activities. They also stressed that Cuernavaca represents an important academic hub that offers considerable resources for carrying out scientific research and collaborations in the city, thus providing a substantial incentive toward academic networks as opposed to local engagement and rural networks within the biosphere reserve. While 
offering benefits to the academic networks, this arguably contributes further to the development of a somewhat buffered and mutually enforced social world of academic researchers within Cuernavaca, as opposed to a more isolated researcher whose social world may enable a more immediate engagement with the local conservation needs of Sierra de Huautla Biosphere Reserve.

\section{Conclusion}

Our study of Sierra de Huautla Biosphere Reserve in Mexico illustrates a considerable disconnect between the integrative human-environment conservation ideals that biosphere reserves were initially envisioned to follow, and the scientific practice encountered today in a biosphere research center that makes a distinction between academic career success on one hand and meaningful conservation research with local engagement on the other hand. Compared to the premises and needs of the integrative goals of the Mexican modality of a biosphere reserve as a conservation model, this case study reports a lack of social and multidisciplinary research concerned with the integration of natural and human dimensions of conservation in the biosphere reserve, and a lack of local relevance even within the mostly natural science-based research that is being conducted.

Researchers in Sierra de Huautla Biosphere Reserve indicate a strong prioritization of foundational biological research, embedded in a composition of scientists with protectionist ideas of conservation that put an exclusive emphasis on the contribution of natural sciences, further reinforced by the pressures of academic evaluation rigor, which encourages efficient laboratory work and high-ranked scientific publications while discouraging long-term and in-depth engagement with local conservation needs. In short, the socio-natural interface that should be guiding conservation research in the biosphere reserve is virtually absent in Sierra de Huautla's research center.

Moreover, this case study suggests that the described disconnect may grow even further over time due to the institutional reward mechanisms and mutual enforcements within the academic social worlds of the scientists that are in place at the research center. Both create an environment for scientists that discourages academic effort toward social or multidisciplinary research, interest in the local relevance of research applications, and a deeper engagement with the conservation needs of the biosphere reserve. Our analysis highlights several reasons why this is happening - for example, because of individual pressures and incentives in their academic work environment, as well as problems within academic management and administration - which offer an in-depth case to 
understand how Mexican research centers associated with specific biosphere reserves may be unable to address integrative and local aspects of their research mandates sufficiently.

The systemic context of these mechanisms at this research center raises the possibility of a structural problem in Mexico's system of academic conservation research related to biosphere reserves and their local needs in general, which we think requires further research at the policy interface between Mexico's conservation research and practice. This concern is consistent with recent academic studies in Latin America that report of conservation scientists who have criticized the character of academic requirements which force them to comply with regulations that are often detrimental to conservation research (Ceballos, 2004; Ceballos et al., 2009; Galindo-Leal, 2000). The lack of interaction among scientists and managers working in Mexican biosphere reserves, along with the lack of research on locally relevant species within natural protected areas, has already been identified as an urgent challenge for the future of management and conservation strategies (Castillo \& Toledo, 2000; Pino-del Carpio et al., 2011). For example, it has been reported that a large amount of ecological and biological research is opportunistically published in the conservation literature, while little focus is given in comparison to policy-relevant information regarding local and regional conservation action (Fazey et al. 2005).

Reports on the performance of Mexican natural protected areas show that protection initiatives that have their own laboratory or are associated with a research institute have been considered very important contributors for the production of natural science-based knowledge (CONABIO, 2012; Halffter, 2011; Urquiza-Haas, 2009). However, the production of knowledge in itself does not necessarily improve the local conservation situation on the ground, nor does it ensure that local interests and effective local management conditions are sufficiently taken into account (Castillo \& Toledo, 2000).

Our findings remind of the critical importance of alignment between the written priorities and the practical conditions of conservation efforts. This small case study of one Mexican research center is in line with similar findings across a growing body of research which suggests that what might be required is not only to increase the number of natural protected areas or strengthen natural science-based research - as is currently advocated in the Mexican environmental literature (Dirzo et al., 2009) — but, fundamentally, a critical re-examination of the culture of conservation research practice.

For example, recent integrative research on indigenous and communityconserved areas in Mexico suggests that these types of environmental initiatives have important conservation benefits (Berkes, 2009; Orozco \& Berkes, 2010; Robson, 2007). These initiatives are not necessarily based on a conventional 
conservation approach that could be effectively supported through multiinstitutional structures, but instead require strong community organizations paired with traditional knowledge-based conservation strategies. Given the potential for biodiversity conservation offered by such alternative initiatives and the challenges of current scientific practice as described in this study, such new strategies could become considered as valuable components of future conservation planning in Mexico, rather than remain outside alternatives while conventional conservation strategies are further expanded (Robson, 2007).

With regard to the scientific environment of conservation researchers, the current conventional ("mainstream") evaluation criteria for academic success in the Mexican scientific community (i.e., based on publications and grant income) poses challenges to local conservation relevance and engagement, and raises the question whether it could be examined for refinement or be revisited for a broader assessment of criteria (Ceballos et al., 2009; Martínez, et al. 2006). Several recent academic reviews and reports have started to question the success of this evaluation system for Mexico's overall research science performance, particularly with respect to scientific and technological engagement in local and regional issues (Alcocer, 2010; Aupetit \& Gérard, 2011; González-Maya \& Cepeda, 2011; Jaso-Sanchez, 2008).

Our presented findings support the need for further research in this regard. García-Frapolli et al. (2009), for example, have argued that Mexico's conservation policy has greatly benefited from the government's long tradition of employing scientists, based on the argument that this valorizes scientific planning over political interests. However, we would like to add that it is also important to look at the power asymmetries, selection mechanisms, and barriers that scientists are facing when carrying out their work. As our study illustrates, the scientists' work is embedded in a larger political realm, which is currently influenced by managerial trans-local discourses of "academic excellence," detached from actual conservation sites to an extent that has made locally relevant science in Mexican conservation research difficult. "Publish or perish" has for too long been presented as an apolitical, "value-free" system under which scientists worldwide are operating. Our findings support the growing critique that is emerging toward the implications of this notion in conservation, and illustrate how the scientific priorities that it creates reflect an underlying political paradigm on numerous levels. This analysis of the research center managing Sierra de Huautla Biosphere Reserve offers a pressing example of how scientist norms, careers, and commitments are embedded within sociopolitical contexts and selection mechanisms, and it reminds us that they are never value-free or neutral, but inherently political. 


\section{References}

Academia de Ciencias de Morelos. (2012). Morelos, Capital del Conocimiento. Retrieved from http://www.acmor.org.mx/

Alcocer, S. (2010). Mesa Plenaria 3: El SNI visto por las instituciones. Privilegia el SNI las trayectorias académicas personales. Revista Conocimiento, 105, 36-38. Retrieved from http://es.scribd.com/doc/32652468/RevistaConocimiento-105

Arlettaz, R., Schaub, M., Fournier, J., Reichlin, T. S., Sierro, A., Watson, J. E. M., \& Braunisch, V. (2010). From publications to public actions: When conservation biologists bridge the gap between research and implementation. BioScience, 60(10), 835-842.

Aupetit, S. D., \& Gérard, E. (2011). El sistema nacional de investigadores en 2009. ¿Un vector para la internacionalización de las élites científicas? Perfiles Educativos, 33(132), 29-47.

Baker, J., Milner-Gulland, E. J., \& Leader-Williams, N. (2012). Park gazettement and integrated conservation and development as factors in community conflict at Bwindi Impenetrable Forest, Uganda. Conservation Biology, 26(1), 160-170.

Berkes, F. (2009). Community conserved areas: Policy issues in historic and contemporary context. Conservation Letters, 2(1), 20-25.

Bezaury-Creel, J., \& Gutiérrez-Carbonell, D. (2009). Áreas naturales protegidas y desarrollo social en México. In J. Sarukhán (Ed.), Capital natural de México. Vol. 2: Estado de conservación y tendencias de cambio (pp. 385-431). México: Comisión Nacional para el Conocimiento y Uso de la Biodiversidad.

Blauert, J., \& Dietz, K. (2004). Of dreams and shadows: Seeking change for the institutionalisation of participation for natural resource management. The case of the Mexican regional sustainable development programme (PRODDERS). London: International Institute for Environment and Development, and Institute of Development Studies.

Brockington, D., Igoe, J., \& Schmidt-Soltau, K. A. (2006). Conservation, human rights, and poverty reduction. Conservation Biology, 20(1), 250-252.

Brockington, D., \& Schmidt-Soltau, K. (2004). The social and environmental impacts of wilderness and development. Oryx, 38:140-142.

Bryant, R. L., \& Bailey, S. (1997). Third world political ecology.

New York: Routledge.

Büscher, B. (2010). Anti-politics as political strategy: Neoliberalism and transfrontier conservation in southern Africa. Development and Change, $41(1), 29-51$. 
Büscher, B. (2013). Transforming the frontier: 'Peace parks' and the politics of neoliberal conservation in southern Africa. Durham: Duke University Press.

Cairns, R. (2011). A critical analysis of the discourses of conservation and science on the Galápagos Islands (Doctoral dissertation). Retrieved from White Rose eTheses Online http://etheses.whiterose.ac.uk/id/eprint/2301

Campbell, L. M. (2010). Studying sea turtle conservation and learning about the world: Insights from social science. Conservation and Society, 8(1), 1-4.

Castillo, A., \& Toledo, V. M. (2000). Applying ecology in the third world: The case of Mexico. BioScience, 50, 66-76.

Ceballos, G. (2004). Ecological research and conservation policy in Mexico. Society for Conservation Biology Newsletter, 11, 13-14.

Ceballos, G., Vale, M. M., Bonacic, C., Calvo-Alvarado, J., List, R., Bynum, N., ... Rodríguez, J. (2009). Conservation challenges for the Austral and neotropical America section. Conservation Biology, 23(4), 811-817. doi: 10.1111/j.15231739.2009.01286.x

Chapron, G., \& Arlettaz, R. (2008). Conservation: Academics should "conserve or perish." Nature, 451(7175), 127.

Clarke, A. E. (1991). Social worlds/arenas theory as organizational theory. In D. R. Maines (Ed.), Social organization and social process: Essays in honor of Anselm Strauss (pp. 119-158). New York: Aldine de Gruyter.

Clarke, A. (2005). Situational analysis: Grounded theory after the postmodern turn. Thousand Oaks, CA: Sage.

Clarke, A., \& Friese, C. (2007). Situational analysis: Going beyond traditional grounded theory. In K. Charmaz \& A. Bryant (Eds.), Handbook of grounded theory (pp. 694-743). London: Sage.

Clarke, A. E., \& Star, S. L. (2008). The social worlds framework: A theory/ methods package. In E. J. Hackett, O. Amsterdamska, M. E. Lynch, \& J. Wajcman (Eds.), The handbook of science and technology studies (3rd ed.) (pp. 113-138). Cambridge, MA: The MIT Press.

Comisión Nacional de Áreas Naturales Protegidas. (2012). Áreas naturales protegidas decretadas. Retrieved from http://www.conanp.gob.mx/que_ hacemos/

CONABIO (Comisión Nacional para el Uso y Conocimiento de la Biodiversidad). (2012). Retrieved from http://www.biodiversidad.gob.mx/pais/pais.html

Contreras-Hernández, H. (1991). Conservación, producción y desarrollo rural: El caso de la reserva de la biosfera "El Cielo", Tamaulipas, México (Unpublished master's thesis). Universidad Autónoma Metropolitana, Unidad Xochimilco, México.

Corbin, J., \& Strauss, A. L. (1990). Grounded theory research: Procedures, canons, and evaluative criteria. Qualitative Sociology, 13(1), 3-21. 
den Outer, B., Handley, K., \& Price, M. (2013). Situational analysis and mapping for use in education research: A reflexive methodology? Studies in Higher Education, 38(10), 1504-1521.

Dirzo, R., González-Montagut, R., \& March, I. J. (2009). Estado de conservación del capital natural de México: Retos y perspectivas. In J. Sarukhán (Ed.). Capital natural de México. Vol. 4: Lecciones aprendidas (pp. 804-809). México: Comisión Nacional para el Conocimiento y Uso de la Biodiversidad.

Dorado, O., Arias, D. M., Alonso, G., \& Maldonado, B. (2002). Educación ambiental para la biodiversidad en el trópico seco de México. Tópicos en educación Ambiental, 4(12), 23-33.

Durand, L., \& Jiménez, J. (2010). Sobre áreas naturales protegidas y la construcción de no lugares. Notas para México. Revista Lider, 16(12), 59-72.

Durand, L., \& Lazos, E. (2008). The local perception of tropical deforestation and its relation to conservation policies in Los Tuxtlas Biosphere Reserve, México. Human Ecology, 36(3), 383-394. doi: 10.1007/s10745-008-9172-7

Durand, L., \& Vázquez, L. B. (2011). Biodiversity conservation discourses. A case study on scientists and government authorities in Sierra de Huautla Biosphere Reserve, México. Land Use Policy, 28(1), 76-82.

Fazey, I., Fischer, J., \& Lindenmayer, D. B. (2005). What do conservation biologists publish? Biological Conservation, 124(1), 63-73.

Figueroa, F., \& Durand, L. (2011, September). Nos importan las cuestiones sociales ? El contexto social en los programas de manejo de las reservas de la biósfera en México. Paper presented at the Quinto Congreso Iberoamericano sobre Desarrollo y Ambiente de REDIBEC, Santa Fé, Argentina. Retrieved from http://fich.unl.edu.ar/CISDAV/upload/Ponencias_y_Posters/Eje01/ Figueroa_Durand/Ponencia \% 20Figueroa \% 20y \% 20 Durand \% 20 REDIBEC \% 202011.pdf

Forsyth, T. (2008). Political ecology and the epistemology of social justice. Geoforum, 39(2), 756-764.

Forsyth, T., \& Sikor, T. (2013). Forests, development and the globalisation of justice. The Geographical Journal, 179(2), 114-121.

Fujimura, J. (1987). Constructing 'do-able' problems in cancer research: Articulating alignment. Social Studies of Science, 17(2), 257-293.

Galindo-Leal, C. (2000). Ciencia de la conservación en América Latina. Interciencia, 25(3), 129-135.

Gallardo, C. (2010). Afecta cambio de nombre al CEAMISH. El Regional com.mx. Retrieved from http://www.elregional.com.mx/index.php?option=com_con tent \&view $=$ article\&id=5678:afecta cambio-de-nombre-al-ceamish-dorado $\&$ catid $=42:$ local $\&$ Itemid $=63$ 
García-Frapolli, E., Ramos-Fernández, G., Galicia, E., \& Serrano, A. (2009). The complex reality of biodiversity conservation through natural protected area policy: Three cases from the Yucatán Península, México. Land Use Policy, 26, $715-722$.

Gerritsen, P. (2002). Diversity at stake: Perspectives on biodiversity and conservation in western Mexico (Unpublished doctoral dissertation). Wageningen Universiteit, The Netherlands.

Gerson, E. M. (1983). Scientific work and social worlds. Science Communication, 4(3), 357-377.

Glaser, B. G., \& Strauss, A. L. (1967). The discovery of grounded theory: Strategies for qualitative research. Chicago: Aldine.

Gómez-Pompa, A., \& Dirzo, R. (Coords.). 1995. Reservas de la biosfera y otras áreas protegidas de México. México D.F.: Instituto Nacional de Ecología Comisión Nacional para el Conocimiento y Uso de la Biodiversidad.

González, M. (2010). En riesgo financiamiento por cambio de denominación de facultades. El Sol de Cuernavaca. Retrieved from http://www.oem.com.mx/ elsoldecuernavaca/notas/n1510273.htm

González-Maya, J. F., \& Cepeda, A. (2011). Ciencia y publicación en Latinoamérica: Retos, perspectivas y causas. Revista Mexicana de Mastozoología, 15, 4-7.

Halffter, G. (2011). Reservas de la biosfera: Problemas y oportunidades en México. Acta Zoológica Mexicana, 27(1), 177-189.

Halffter, G., \& Ezcurra, E. (1989). Evolution of the biosphere reserve concept. In W. P. Gregg, S. L. Krugman, \& J. D. Wood (Eds.), Proceedings of the symposium on biosphere reserves, Fourth World Wilderness Congress (pp. 188-207). Atlanta: U. S. Department of the Interior.

Jasanoff, S. (Ed.). (2004). States of knowledge: The co-production of science and the social order. New York: Routledge.

Jaso-Sanchez, M. A. (2008, June). Evaluating the operation of a peer review programme: Looking for impacts in university-industry collaboration practices in the medicinal plants sector. Working Paper presented at the Research Seminar Department of Institutional Studies (DESIN) Autonomous Metropolitan University, Cuajimalpa Campus, Mexico.

Kellert, S. R., Mehta, J. N., Ebbin, S. A., \& Lichtenfeld, L. L. (2000). Community natural resource management: Promise, rhetoric, and reality. Society \& Natural Resources, 13(8), 705-715.

Koleff, P., \& Urquiza-Haas, T. (Coords.). (2011). Planeación para la conservación de la biodiversidad terrestre en México: Retos en un país megadiverso. Mexico D.F.: Comisión Nacional para el Conocimiento y Uso de la BiodiversidadComisión Nacional de Áreas Naturales Protegidas. 
Lane, M. B. (2003). Decentralization or privatization of environmental governance? Forest conflict and bioregional assessment in Australia. Journal of Rural Studies, 19(3), 283-294.

Le Billon, P. (2001). The political ecology of war: Natural resources and armed conflicts. Political Geography, 20(5), 561-584.

Martínez, M., Manson, R., Balvanera, P., Dirzo, R., Soberón, J., García-Barrios, L. E., ... Sarukhán, J. (2006). The evolution of ecology in México: Facing challenges and preparing for the future. Frontiers in Ecology and the Environment, 4(5), 259-267.

Noble, I. R., \& Dirzo, R. (1997). Forests and human dominated ecosystems. Science, 277(5325), 522-552.

Orozco, A. Q., \& Berkes, F. (2010). Role of linkages and diversity of partnerships in a Mexican community-based forest enterprise. Journal of Enterprising Communities: People and Places in the Global Economy, 4, 148-161.

Pino-del Carpio, A., Villarroya, A., Arino, A., Puig, J., \& Miranda, R. (2011). Communication gaps in knowledge of freshwater fish biodiversity: Implications for the management and conservation of Mexican biosphere reserves. Journal of Fish Biology, 79, 1563-1591.

Reyes Morales, D., \& Dorantes Flores, A. (2007). Jugar para educar, educar para conservar. Hypatia, 22, 10-14. Retrieved from http://hypatia.morelos.gob. $\mathrm{mx} /$ index.php?option $=$ com_content $\&$ task $=$ view $\& i d=80 \&$ Itemid $=20$

Robson, J. P. (2007). Local approaches to biodiversity conservation: Lessons from Oaxaca, southern Mexico. International Journal of Sustainable Development, 10(3), 267-286.

Santana-Castellón, E. (2013, February). The Sierra de Manantlán Biosphere Reserve. Lecture presented at the Latin American and Iberian Institute, University of New Mexico. Retrieved from http://unmevents.unm.edu/ EventList.aspx fromdate $=2 / 14 / 2013 \&$ todate $=2 / 14 / 2013 \&$ display $=$ Day $\&$ typ e=public\&eventidn $=472 \&$ view $=$ EventDetails\&information_id $=1653$

Sievanen L., Campbell, L. M., \& Leslie, H. M. (2012). Challenges to interdisciplinary research in ecosystem-based management. Conservation Biology, 26(2), 315-323.

Simonian, L. (1995). Defending the land of the jaguar: A history of conservation in Mexico. Austin: University of Texas Press.

Stairs, G. S. (2007). The social construction of sustainable rural futures in the world network of biosphere reserves (Doctoral dissertation). University of Wisconsin-Madison. Available from ProQuest Dissertations and Theses database. (UMI No. 3294172)

Tuunainen, J. (2005). When disciplinary worlds collide: The organizational ecology of disciplines in a university department. Symbolic Interaction, 28(2), 205-228. 
UNESCO (United Nations Educational, Scientific and Cultural Organization). (2013). The world network of biosphere reserves. Ecological Sciences for Sustainable Development. Retrieved from http://www.unesco.org/new/ en/natural-sciences/environment/ecological-sciences/man-and-biosphereprogramme/

Urquiza-Haas, E. G. (2009). Análisis de capacidades nacionales para la conservación in situ. In Capacidades para la conservación y uso sustentable de la biodiversidad (pp. 51-94). México D.F.: CONABIO-PNUD.

Vayda, A. P., \& Walters, B. B. (1999). Against political ecology. Human ecology, 27(1), 167-179.

Young, E. (1999). Local people and conservation in Mexico's El Vizcaíno Biosphere Reserve. Geographical Review, 89(3), 364-390. 
This text taken from Human Ecology Review Volume 20, Number 2, 2014, published 2014 by ANU Press, The Australian National University, Canberra, Australia. 